\title{
Law Education for Civil Engineers
}

\author{
Klaus Holschemacher* and Ulrike Quapp \\ HTWK Leipzig University of Applied Sciences, Germany
}

Submission: March 16, 2019; Published: March 26, 2019

*Corresponding author: Klaus Holschemacher, HTWK Leipzig University of Applied Sciences, Germany

Abstract

Law education of civil engineers always is a hard-discussed topic. This short paper shows its importance and recommends, at a German example, the educational level, the contents and the extent of law topics in higher and further education of civil engineers.

Keywords: Civil Engineering Education; Further Training; Legal Education; Construction Law

\section{Introduction}

As demanding the job of a civil engineer is, as challenging are the today's legal requirements on construction projects. Nevertheless, there is widespread opinion that civil engineering is a profession where legal knowledge and skills are not necessary at all. But construction projects normally touch many different legal aspects, such as of civil and public construction law, neighbor law, environmental law, professional rules of engineers and sometimes criminal law as well. Of course, architects and construction managers are more involved in law related construction issues than a civil engineer is. However, also the civil engineers every day work live is influenced by diverse rules and regulations. A fundamental understanding of the home countries legal system, of legal relationships in construction projects as well as relevant law sources are necessary to avoid legal pitfalls that possibly can result in a financial or personal disadvantage.

In the authors' opinion, civil engineers need a minimum legal knowledge relating to their professional field to be able to do a high-quality work. In Germany, this point of view is supported by the construction industry, professional associations such as the Chambers of Engineers and public employers which all are requiring law topics for civil engineering education [1]. The difficulty is to decide which contents on which level universities should offer and to what extents.

\section{Law Education in Civil Engineering Study Programs}

Legal topics normally only play a minor role in civil engineering education. Hence, most of the German higher education institutions offer law contents in civil engineering study programs on different educational levels and to various extents. Students can, for example, come in contact with fundamental information about the home country's legal system or attend courses in public construction and civil construction law, city or transportation infrastructure planning - depended from the respective university.

Of course, there are noteworthy arguments against law contents in civil engineering study programs, such as the reduced time for engineering-related courses [2]. Furthermore, a high number of civil engineering students normally show no or only little interested in legal topics although construction projects have become more and more legally demanding in the last years. Legal and technical rules and regulations have increased in extent and complexity with the result that civil engineers come in contact with legal topics much more intensively. Thus, to guarantee graduates' employability and to prepare graduates well for their future jobs, law education is necessary.

Civil engineers must not learn all aspects of law. It is important to know basics of the legal system in which they will work, to be able to name relevant legal sources and to know where relevant rules and regulations can be found. That allows civil engineering graduates to deepen their knowledge if later needed. For taking away the fear of coming in contact with legal issues, basic knowledge in law is necessary. By teaching that, universities enable graduates to recognize risks in their daily worklife and ensure the ability to decide whether there is a problem that they can solve by themselves or if they better should search for legal counsel.

Law contents in civil engineering programs do not necessarily need a lot of time. One solution can be to include law contents in civil engineering courses and not to teach the topic separately. For example modules such as "building construction" or "road planning" could contain legal planning aspects. Of course, it will reduce the time for engineering contents as well. Furthermore, 
the respective lecturer will be challenged to teach law contents beside the subject-related contents. The better solution will be to offer law lectures in a separate course and with experienced law experts as lecturers. In the opinion of the authors, in a bachelor program 3 contact hours per week within 14 weeks resulting in 4 credit points based on the European Credit Transfer System (more information: Bologna Working Group on Qualification Frameworks [3]) are sufficient to teach basics of the German legal system and of building-related fields of law. 4 credit points in Germany correspond with 120 students' workload and are around $2 \%$ of the total amount of credit points of a bachelor program. To ensure employability and a comparable educational level of the graduates, law education in civil and structural bachelor programs should be compulsory. In master programs, students could have the opportunity to choose more individually, building upon the basic law education on bachelor level.

\section{Legal Further Training Beside the Job}

Because law is undergoing continuous revisions and civil engineers normally change their professional field more than once in their worklife, a further legal education seems necessary to stay up to date and to avoid disadvantages for the employer or themselves. In Germany, legal regulations require an ongoing further education for special groups of civil engineers and professional associations for their members. However, even if further education on the field of law is not compulsory, it will be recommendable. The permanently updating rules and regulations relating to construction processes require knowledge of the newest legal and technical development as well as current court decisions to ensure a high-quality work.
Further legal training in Germany is offered by universities, professional associations and private education institutions.

\section{Conclusion}

The conclusion is that law education up to a specific level is necessary to ensure the qualification to work professionally in design and construction. This allows the building industry, employers and the civil engineers themselves to save time and money that otherwise might have been spent for legal consulting or for corresponding penalties as well as lawsuits. Thus, the authors recommend the inclusion of a compulsory law module with contents of legal basics as well as public and private construction law in each civil engineering bachelor program in Germany.

\section{References}

1. AS Bau-Alliance for the Accreditation of Courses of Studies in Construction (2018) Reference Frame for Courses of Studies in Civil Engineering (Bachelor).

2. Quapp U, Holschemacher K (2014) The Importance of Construction Law in Civil and Structural Engineering Education. In: Chantawarangul $\mathrm{K}$, et al. (Eds.), Sustainable Solutions in Structural Engineering and Construction. Proc. $2^{\text {nd }}$ Australasia and South East Asia Structural Engineering and Construction Conference-ASEA-SEC-02, Bangkok, Thailand.

3. Bologna Working Group on Qualification Frameworks (2005) A Framework for Qualifications of the European Higher Education Area: 59. Bredgade: Ministry of Science, Technology and Innovation Denmark, Denmark, pp. 1-200.

\footnotetext{
Your next submission with Juniper Publishers will reach you the below assets

- Quality Editorial service

- Swift Peer Review

- Reprints availability

- E-prints Service

- Manuscript Podcast for convenient understanding

- Global attainment for your research

- Manuscript accessibility in different formats

( Pdf, E-pub, Full Text, Audio)

- Unceasing customer service
}

Track the below URL for one-step submission https://juniperpublishers.com/online-submission.php 